\title{
PROTÓTIPO DE EQUIPAMENTO ESTERILIZADOR PORTÁTIL DE AMBIENTES.
}

\author{
Semana Online Científica de Engenharia, 1a edição, de 25/10/2021 a 27/10/2021
}

ISBN dos Anais: 978-65-81152-19-2

\begin{abstract}
OLIVEIRA; Daniel Rodrigues Oliveira 1, SILVA; Kairo Bruno Almondes da Silva 2, SILVA;
\end{abstract} Kawan Felipp Pascoa da Silva ${ }^{3}$

\section{RESUMO}

No ano de 2020 e 2021 a pandemia do COVID-19 passou a fazer parte do cotidiano de todos os cidadãos, e devido a proliferação da COVID em âmbito global, e também devido a facilidade de contagio desse referente vírus, mostrou-se uma grande necessidade, tanto de buscar formas alternativas de proteção contra o mesmo, já que os equipamentos de proteção individual (EPI's) acabaram mostrando uma escassez referente a acessibilidade de pose dos mesmos, como também na alta demanda constante de limpeza nos ambientes hospitalares e nos ambientes públicos onde ocorre um grande fluxo de bactérias e do vírus oportunista tratado em questão. Nesse contexto atual, também se mostrou necessário uma forma alternativa de combater o vírus, pelo fato de que ocorreu, de forma global, uma alta elevação de concentração de pacientes diagnosticados com o vírus da COVID-19. O presente projeto de pesquisa tem o objetivo de desenvolver um equipamento que além de ser portátil, também utiliza a radiação ultravioleta para o combate do coronavírus, reduzindo a carga viral de um ambiente. As lâmpadas de UV são as fontes de Radiação mais usadas para eliminação de germes e bactérias. Sendo lâmpadas projetadas especialmente para produzir raios de UV Germicida, com vidro especial que bloqueia os raios que geram ozônio. Até o presente momento de execução do projeto foi desenvolvido a programação para Arduíno para o funcionamento de todo equipamento, assim como o esquema eletrônico necessário, e fabricado parte do protótipo com a parte estrutural. Até o momento conclui-se que o protótipo conseguiu realizar parcialmente os objetivos almejados.

PALAVRAS-CHAVE: Germicida, Raios Ultravioleta, EPC 